Asian J. Med. Biol. Res. 2016, 2 (2), 348-351; doi: 10.3329/ajmbr.v2i2.29080

\author{
Asian Journal of \\ Medical and Biological Research \\ ISSN 2411-4472 (Print) 2412-5571 (Online) \\ www.ebupress.com/journal/ajmbr
}

\title{
Short Communication \\ Comparative performances of hilly chicken and naked neck hilly chicken at Naikhongchari hilly areas of Bangladesh
}

\author{
Md. Azharul Islam Talukder ${ }^{1}$, Md. Ashadul Alam², Md. Moklesur Rahman ${ }^{2}$, Md. Abu Hemayet ${ }^{1}$ and Md. \\ Asadul Islam ${ }^{3}$ \\ ${ }^{1}$ Goat and Sheep Division, Bangladesh Livestock Research Institute, Savar, Dhaka, Bangladesh \\ ${ }^{2}$ System Research Division, Bangladesh Livestock Research Institute, Regional Station, Naikhongchari, \\ Bandarban, Bangladesh \\ ${ }^{3}$ Department of Livestock Services, Bangladesh
}

*Corresponding author: Md. Ashadul Alam, System Research Division, Bangladesh Livestock Research Institute, Regional Station, Naikhongchari, Bandarban, Bangladesh. E-mail: apple_bau118@yahoo.com

Received: 10 May 2016/Accepted: 02 June 2016/ Published: 30 June 2016

\begin{abstract}
A total of 115 hilly chickens (92 female and 23 males) and 35 naked neck hilly Chickens (28 females and 7 males) were reared in open sided poultry house for 10 months period to compare their productive and reproductive performances. The mean body weights of adult female and male hilly birds and naked neck hilly birds were 2244, 2005 and 2664, 2576 g respectively. The age at first egg of both type of birds were 147 and 159 days respectively and hen-day egg production were $27 \pm 1.4$ and $35 \pm 3.3$ respectively. The average egg weight was $41 \pm 4$ and $38 \pm 3.6 \mathrm{~g}$ respectively. Both type of bird per day average feed consumption were $97.61 \pm 11$ and $102 \pm 22 \mathrm{~g}$ and mortality were $15.56 \pm 3.7$ and $11.42 \pm 2.7$ percent respectively. The average hatchability percentage performed by 14 broody hens reared on litter floor was $67.5 \pm 10$ and $57 \pm 22$ percent respectively. The average hatching egg weight and chick weight were $47.28 \pm 3,41.48 \pm 1$ and $31.4 \pm 3,29.6 \pm 4 \mathrm{~g}$ respectively. The body weight of growing hilly bird and Naked Neck hilly bird after eleven weeks of age were $727.3 \pm 17.4$ and $645 \pm 97.6 \mathrm{~g}$, respectively and Feed conversion ratios (FCR) were 3.39 and 3.34 respectively. It was concluded that Hilly chicken improved by body weight than previous year and both feathered and Naked Neck Hilly chicken given an indication of meat type native chicken and required to reproduce to have large stock for undertaking conservation and further improvement programme.
\end{abstract}

Keywords: hilly chicken; naked neck hilly chicken; egg production; conservation; Naikhongchari

\section{Introduction}

In Bangladesh, several types of indigenous chicken are found such as hilly, Naked Neck, Aseel, Yeasine, native dwarf, Frizzled plumage and common native birds of non-idiosyncratic typical type (Das et al., 2008). Some dwarf chickens and Red Jungle Fowls can also be seen in the country. Hilly chicken and Naked Neck hilly chicken are found in hilly areas of the Chittagong region and reared for local consumption and its egg and meat has a unique taste, is regarded as a delicacy, and is popular among consumers. Indigenous chickens are characterized as dual purpose birds due to their ability to supply both meat and eggs for human consumption. Local non-descript coloured chicken is a vital source of tasty meat and eggs and more acceptable to rural people (Barua and Howlider, 1990). Ganabadi et al. (2009) reported that indigenous chicken is always thought to be better in term of carcass composition than commercial broilers due to its low fat content. The local people always try to find the indigenous (desi) cockerel for its tenderness and special taste (Ahmed and Ali, 2007). Indigenous chickens are considered very valuable in the rural communities because they fulfill major functions and benefits in the livelihood of rural families. Indigenous chickens are broody, able to take care of their own chicks (Horst, 1989). The Naked neck chicken has the ability to adapt, survive, perform and reproduce under 
harsh, hot and humid climatic conditions better than the normal feathered birds (Yakubu et al., 2008). Faruque et al. (2013) reported that hilly chicken was superior to non-descriptive deshic and naked neck in terms of body weight gain. The heavier body size of the hilly chickens indicated that it can be used as slow growing meat type chicken in Bangladesh. Rahman et al. (2012) observed 937g body weight of Hilly chicken with 2.89 feed conversion efficiency at 10 weeks of age. As the market price of hilly chicken are much higher than commercial table birds, so benefit-cost can be analyzed to find their economic potentiality. Indiscriminate random breeding among native chicken and unplanned crossing with exotic breed have been eroding the original characteristics of native chicken. So the local genetic resources have been going to be under threat gradually. Conservation and preservation of genetic resources as insurance against future needs has become a topic of mounting concern (Crowford, 1984). There is little information and little research studies has been done to know the productive and reproductive performance of native chicken of hilly regions. Although few works has been done on hilly chicken but the productive potentiality of Naked Neck hilly chicken is not well documented. The local germplasm of hilly chicken and Naked Neck hilly chicken should be collected and conserved precisely for future use and selection for pure breeding is necessary for their development as a meat producing native bird. Therefore, this study was undertaken with the objectives of the Productive and Reproductive Performances of hilly chicken and naked neck hilly chicken and their conservation and improvement at hilly areas.

\section{Materials and Methods}

The experiment was conducted in open sided poultry house at Naikhongchari regional station Research farm of BLRI for 10 months period. A total of 115 adult hilly chickens (92 females and 23 males) and 35 adult naked neck hilly chickens ( 28 females and 7 males) were placed in colony cages as 5 birds ( 4 females and 1 male) in a cage. The chicks were reared on floor, littered with rice husk. Sufficient number of feeders and drinkers were placed in the poultry house. Standard starter, grower and layer feed was offered adlibitum and there was a continuous supply of fresh drinking water during rearing period. A vaccination schedule was followed against Ranikhet and Fowl Pox diseases. Birds were de-wormed on a regular interval. Necessary hygienic measure was taken to ensure bio-security. Natural hatching was performed by mother hen reared on litter (rise husk) floor and conventional bamboo basket was used as hatching nest. Data on egg production, egg weight, fertility, hatchability, feed consumption, body weight and mortality were recorded regularly.

The statistical analysis was done using 'SPSS' 2011 statistical programme to compute analysis of variance (ANOVA) for randomized complete block design (RCBD). Differences among the treatment means were determined by Duncan's Multiple Range Test (DMRT) (Duncan, 1955).

\section{Results and Discussion}

The average body weight of both type of adult birds were shown in Table 1, where up to 30 weeks of age. The adult body weight of hen and cock of hilly chicken were higher than that of naked neck hilly chicken and was no significant difference.

Table 1. Performance of hilly chicken and naked neck hilly chicken at Naikhongchari regional station.

\begin{tabular}{llll}
\hline Parameters & Hilly chicken & Naked neck hilly chicken & Level of \\
\cline { 2 - 4 } & Mean \pm SE & Mean \pm SE & NS \\
\hline Body weight of adult hence $(\mathrm{g})(30 \mathrm{wks})$ & $2244 \pm 134$ & $2005 \pm 79$ & $\mathrm{NS}$ \\
Body weight of adult cock $(\mathrm{g})(30 \mathrm{wks})$ & $2664 \pm 68$ & $2576 \pm 68$ & $\mathrm{NS}$ \\
Egg production (H.D) $\%$ & $27 \pm 1.4$ & $35 \pm 3.3$ & $\mathrm{NS}$ \\
Egg weight $(\mathrm{g})$ & $41 \pm 4$ & $38 \pm 3.6$ & $\mathrm{NS}$ \\
Age at $1^{\text {st }}$ egg $(\mathrm{d})$ & 147 & 159 & $\mathrm{NS}$ \\
Feed consumption (g/bird/d) & $97.61 \pm 11$ & $102 \pm 22$ & $\mathrm{NS}$ \\
Mortality $(\%)$ & $15.56 \pm 3.7$ & $11.42 \pm 2.7$ & \\
\hline
\end{tabular}

However, the egg production of hilly chicken was reduced than previous year and there was no significant difference between hilly chicken and naked neck hilly chicken. Feed consumption of hilly chicken was slightly higher than Naked neck hilly chicken but was no significant difference. There was no significant difference of the age at first egg and mortality among the breeds.

Hatching performances were summarized in Table 2. There was no significant difference of hatchability between hilly and naked neck hilly chicken hatched by broody hens. 
Table 2. Hatching performance of hilly and naked neck hilly chicken as hatched by broody hens.

\begin{tabular}{lllll}
\hline Types of Bird & \multirow{2}{*}{ Egg set (No.) } & Egg weight(g) & Hatchability (\%) & Chick weight $(\mathrm{g})$ \\
\cline { 3 - 5 } & & Mean \pm SE & Mean \pm SE & Mean \pm SE \\
\hline Hilly Chicken & 153 & $47.28 \pm 3$ & $67.5 \pm 10$ & $31.4 \pm 3$ \\
Naked Neck Hilly Chicken & 61 & $41.48 \pm 1$ & $57 \pm 22$ & $29.6 \pm 4$ \\
Level of Significance & & NS & NS & NS \\
\hline
\end{tabular}

However, the lower hatchability in naked neck hilly chicken might be due to the reason of summer season affect on natural hatching process.

The performance of hilly chicks and naked neck hilly chicken are shown in Table 3. There was no significant difference of body weight between hilly chicks and naked neck hilly chicks at day-old, 9 and 11 weeks of age.

Table 3. Performance of both growing hilly and naked neck hilly birds reared up to 11 weeks of age at Naikhongchari regional station

\begin{tabular}{|c|c|c|c|c|}
\hline Parameters & & $\begin{array}{l}\text { Hilly chicks } \\
\text { Mean } \pm S E\end{array}$ & $\begin{array}{l}\text { Naked neck hilly chicks } \\
\text { Mean } \pm \text { SE }\end{array}$ & $\begin{array}{l}\text { Level of } \\
\text { significance }\end{array}$ \\
\hline \multirow{6}{*}{ Body weight $(\mathrm{g}) \quad$ Age $(\mathrm{Wk})$} & Day old & $31.4 \pm 10$ & $29.6 \pm 4$ & NS \\
\hline & 2 & $85.9 \pm 1.7$ & $60 \pm 5.3$ & ** \\
\hline & 5 & $223.4 \pm 5$ & $157.8 \pm 18.8$ & ** \\
\hline & 7 & $350.1 \pm 7.4$ & $226.3 \pm 36.2$ & $* *$ \\
\hline & 9 & $473.5 \pm 11.1$ & $450.6 \pm 77.9$ & NS \\
\hline & 11 & $727.3 \pm 17.4$ & $645 \pm 97.6$ & NS \\
\hline Feed Consumption (g) & & 2470 & 2160 & \\
\hline Feed Conversion Ratio (FCR) & & 3.39 & 3.34 & \\
\hline Mortality (\%) & & $6.11 \pm 3.75$ & $7.14 \pm 2.14$ & NS \\
\hline
\end{tabular}

The body weight of Hilly chicks at 9 weeks of age was higher than that of Faruque et al. (2013) of $373 \mathrm{~g}$ at 8 weeks of age and lower than Rahman et al. (2013) of $636 \mathrm{~g}$ at 9 weeks, and Rahman et al. (2013) $503 \mathrm{~g}$ at 8 weeks of age. The body weight of naked neck hilly chicks at 9 weeks of age was higher than that of plain land naked neck chicken $(381 \mathrm{~g})$ at 8 weeks as reported by Faruque et al. (2013). The average feed consumption per bird of Hilly chick was higher than that of naked neck hilly chicks up to 11 weeks of age. However, the feed conservation ratio of naked neck hilly chicks was slightly better than that of hilly chicks. The mortality of hilly chicks was slightly lower than that of naked neck hilly chicks up to 11 weeks of age.

\section{Conclusions}

From the results of this study, it was revealed that the hilly chicken and naked neck hilly chicken given an indication of meat type native chicken. Hilly chicken improved by body weight than previous year. It may be suggested that both type of chicken require reproducing to have large stock for undertaking conservation and further improvement programme.

\section{Conflict of interest}

None to declare.

\section{References}

Ahmed ST and MA Ali, 2007. Performance of Synthetic, Desi, Synthetic X Desi and Synthetic X Star cross brown chicken at marketing. Proceedings of the $5^{\text {th }}$ International Poultry Show and Seminar, organized by World's Poultry Science Association, Bangladesh Branch, 01-03 March, 2007, pp. 18-25.

Barua A and MAR Howlider, 1990. Prospect of native chicken in Bangladesh, Poultry Advisor, 23:57-61.

Bhuiyan AKFH, MSA Bhuiyan and GK Deb, 2005. Indigenous chicken genetic resources in Bangladesh: Current status and future outlook. Animal Genetic Resources Information's Bulletin, 36: 73-84.

Chowdhury SD, S Ahmed and MA Hamid, 2006. Improved feeding of Deshi chicken reared in confinement. The Bangladesh Veterinarian, 23: 29-35.

Das SC, SD Chowdhury, MA khatun, M Nishibori, N Isobe and Y Youshimura, 2008. Poultry production profile and expected future projection in Bangladesh. World's Poultry Science Journal, 64: 99-117. 
Faruque S, AKFH Bhuiyan, MSA Bhuiyan, MN Islam and MM Rahman, 2012. Conservation and improvement of indigenous chicken. Paper presented in Annual Research Review Workshop, organized by Bangladesh Livestock Research Institute, Savar, Dhaka-1341. 24-25 June, 2012, pp. 68-69.

Faruque S, AKFH Bhuiyan, MS Islam, MM Rahman and MN Islam, 2013. Breeding for the Improvement of Indigenous Chicken in Bangladesh: Performance of Second Generation. Paper presented in Annual Research Review Workshop, organized by Bangladesh Livestock Research Institute, Savar, Dhaka-1341.

Faruque S, MS Islam, MA Afroz and MM Rahman, 2013. Evaluation of the performance of Native chicken and estimation of heritability for body weight. Journal of Bangladesh Academy of Sciences, 37: 93-101.

Faruque S, MM Rahman and MN Islam, 2011. Evaluation of the performance of native chickens and estimation of genetic parameter of body weight. Proceedings of the $7^{\text {th }}$ International Poultry Show and Seminar, organized by World's Poultry Science Association, Bangladesh Branch, 25-27 March 2011, pp. 199-206.

Faruque S, NR Sarker, MN Islam and MSK Sarker, 2007. Performance of native chickens under intensive system. Journal of Bangladesh Agricultural University, 5: 283-288.

Khan AG, 1983. Improvement of Desi bird (Part-2). Poultry Adviser, 16: 67-78.

Rahman MM, MM Islam and UK Mohanta, 2011. Conservation and improvement of Hilly chicken. Proceedings of the Annual Research Review Workshop, organized by Bangladesh Livestock Research Institute, Savar, Dhaka-1341, pp. 96-99.

Rahman MM, S Faruque, MN Islam, M Asaduzzaman, MM Islam and MAI Talukder, 2012. Evaluation of meat production potentiality of Hilly chicken. Proceedings of the Annual Research Review Workshop, organized by Bangladesh Livestock Research Institute, Savar, Dhaka-1341, pp. 86-88.

Rahman MM, S Faruque, MM Islam and A Mahmud, 2013. Productive and reproductive performances of Hilly and Jungle Fowl. The Agriculturists, 11: 10-13.

Rahman MM, S Faruque, MS Islam, MN Islam and Rahid, 2013. Comparison of growth performance and meat yield of Hilly chicken under two feeding regimes. The Agriculturists, 11: 38-43.

Singh A and R Singh, 1989. Alternative selection plans of improving dam line of broilers. Indian J. Poult. Sci., 24: $15-19$.

Statistical Package for the Social Sciences (SPSS) 2011. Statistical Programme (Version 11.5).

Talukder MAI, MM Rahman, M Asaduzzaman, MA Alam and NG Das, 2014. Conservation and improvement of Hilly chicken at Naikhongchari regional station. Proceedings of annual research Review workshop 201213, 19-20 June 2013, Bangladesh Livestock Research Institute, Savar, Dhaka 1341.

Talukder MAI, MA Alam and MM Rahman and MA Hemayet, 2015. Conservation and improvement of Hilly chicken at Naikhongchari regional station. Bangladesh Livestock Research Institute, Annual Research Review Workshop 17-18 June, 2015, pp. 69-70. 